\title{
Pebandingan Metode Analisa Kadar Besi antara Serimetri dan Spektrofotometer UV-Vis dengan Pengompleks 1,10- Fenantrolin
}

\author{
Dewa Ayu Tetha E.S ${ }^{1}$ dan R. Djarot Sugiarso K. $S^{1 *}$ \\ ${ }^{1}$ Jurusan Kimia, Fakultas Matematika dan Ilmu Pengetahuan Alam, Institut Teknologi Sepuluh Nopember (ITS) \\ *djarot@chem.its.ac.id
}

\begin{abstract}
Abstrak- Penelitian mengenai penentuan kadar besi dalam sampel menggunakan metode serimetri dan spektrofotometer UV-Vis telah dilakukan. Sampel dibuat dari larutan $\mathrm{Fe}^{2+} 50 \mathrm{ppm}$ yang direaksikan dengan pengompleks 1,10-fenantrolin sehingga terbentuk kompleks $\mathrm{Fe}(\mathrm{II})$ fenantrolin. Hasil pengukuran panjang gelombang maksimum dari kompleks $\mathrm{Fe}(\mathrm{II})$-fenantrolin sebesar $510 \mathrm{~nm}$, dan pada kurva kalibrasi yang dibuat, didapatkan persamaan linier y = 0,2067x + 0,0030 dengan nilai regresi $r^{2}=0,9997$. Pengukuran kadar besi dilakukan pada sampel yang telah diencerkan menjadi 1,5 dan 3 ppm. Hasil analisa menunjukkan bahwa kadar besi dalam sampel paling baik diukur menggunakan spektrometer UV-Vis yaitu dengan persen recovery dan nilai CV yang didapat sebesar 105,596\% dan $0,64 \%$ (1,5 ppm), 101,919\% dan 0,91\% (3 ppm) daripada menggunakan metode serimetri, dimana hasil yang didapat sebesar $111,111 \%$ dan $6,18 \%$ (1,5 ppm), $111,731 \%$ dan $6,25 \%$ (3 ppm)..
\end{abstract}

Kata kunci : Fe(II)-fenantrolin; kadar besi; CV; persen recovery; serimetri; spektrofotometer UV-Vis.

\section{Pendahuluan}

Mineral merupakan salah satu unsur nutrisi yang diperlukan oleh tubuh. Sebagian besar mineral berguna bagi metabolisme tubuh, keseimbangan kadar air dan kesehatan tulang. Beberapa jenis mineral yang telah ditemukan, memiliki manfaat yang berbeda-beda bagi tubuh. Salah satunya adalah zat besi. Zat besi merupakan mineral mikro yang esensial bagi tubuh, yang artinya, keberadaanya sangat diperlukan di dalam tubuh dalam jumlah tertentu ${ }^{[5]}$.

Zat besi merupakan senyawa penting yang diperlukan oleh tubuh antara lain untuk pertumbuhan, aktivitas otot, pengangkutan oksigen, fungsi otak, kekebalan tubuh, pengatur suhu tubuh, dan yang paling penting senyawa ini diperlukan dalam hemopobesis atau pembentukan darah yaitu pada sintesa hemoglobin untuk mencegah anemia ${ }^{[3]}$.

Kekurangan zat besi dapat menyebabkan gangguan susunan syaraf pusat, dapat mengurangi prestasi kerja, kecerdasan terhambat, menurunnya kekebalan terhadap infeksi, dan timbulnya gejala anemia, yang akan diwujudkan sebagai kondisi seperti kelemahan otot, kelelahan, gangguan pencernaan dan kerusakan kognitif. Selain kekurangan, kelebihan zat besi juga berdampak buruk bagi tubuh, dimana gejala yang ditimbulkan diantaranya adalah meningkatnya denyut jantung, sakit kepala, mengigau, mual dan muntah serta pingsan. Namun, kelebihan zat besi jarang terjadi karena makanan, melainkan disebabkan oleh suplemen zat besi ${ }^{[3]}$.

Suplemen penambah zat besi yang paling sering dianjurkan adalah besi (II) sulfat. Suplemen ini berbentuk tablet dan digunakan untuk mengatasi anemia terutama anemia defisiensi besi. Sebelum beredar, suplemen harus diuji terlebih dahulu mutu dan kualitasnya, termasuk penetapan kadar besi yang terkandung dalam suplemen tersebut ${ }^{[7]}$.

Pada tahun 2010, Setyowati melakukan penelitian mengenai penetapan kadar besi, dengan membandingkan metode serimetri dan spektrofotometri visible menggunakan pereaksi $\mathrm{KMnO}_{4}$-salisilat. Pada studi tersebut, besi (II) 
dioksidasi menjadi besi (III) menggunakan $\mathrm{KMnO}_{4}$, yang kemudian direaksikan dengan asam salisilat agar larutan menjadi berwarna, yaitu kompleks berwarna ungu. Setelah itu diukur kadarnya menggunakan spektrofotometri UV-Vis. Namun, kekurangan dari penggunaan instrumen spektrofotometer UV-Vis ini diantaranya senyawa yang akan dianalisa harus memiliki gugus kromofon (gugus pembawa warna), dan memiliki ikatan rangkap terkonjugasi serta mempunyai panajng gelombang yang terletak pada daerah ultraviolet atau visible. Selain itu, hasil absorbansi yang terukur dapat dipengaruhi oleh $\mathrm{pH}$ larutan, suhu, adanya zat pengganggu dan kebersihan dari kuvet.

Studi penetapan kadar besi juga telah dilakukan sebelumnya oleh Eng Chan Kim dan Nikolaev tahun 1995 menggunakan berbagai macam metode, diantaranya adalah metode serimetri, permanganometri, spektrofotometri dan spektrofotometri serapan atom. Studi yang dilakukan tersebut menghasilkan persentase eror, yaitu $0,085 \%$ pada permanganometri, $2,425 \%$ pada spektrofotometri dan $0,862 \%$ pada spektrofotometri serapan atom.

Berdasarkan latar belakang diatas, dalam rangka pemilihan metode yang sesuai, maka dalam penelitian kali ini akan membahas mengenai metode yang paling baik antara metode serimetri dan spektrofotometer UV-Vis. untuk analisa kadar besi berdasarkan pembentukan kompleks $\mathrm{Fe}(\mathrm{II})$ fenantrolin.

\section{Percobaan}

\subsection{Pembuatan Larutan Stok}

Penelitian ini diawali dengan membuat berbagai larutan stok antara lain larutan $\mathrm{Fe}$ (II) 50 ppm sebagai larutan besi standar, larutan 1,10fenantrolin 1000 ppm sebagai pengompleks, larutan $\mathrm{Ce}^{4+} 150 \mathrm{ppm}$ sebagai titran, larutan buffer asetat $\mathrm{pH} 4,5$ sebagai pengontrol suasana asam. Aseton dan aqua DM sebagai pelarut.

\subsection{Penentuan Panjang Gelombang Maksimum dan Pembuatan Kurva Kalibrasi}

Pengukuran panjang gelombang maksimum menggunakan larutan yang terbuat dari campuran $0,5 \mathrm{~mL}$ larutan $\mathrm{Fe}^{2+} 50 \mathrm{ppm}$ dan $1,5 \mathrm{~mL}$ larutan 1,10-fenantrolin $1000 \mathrm{ppm}$ yang dimasukkan ke dalam labu ukur $10 \mathrm{~mL}$. Campuran larutan didiamkan selama \pm 60 menit, lalu ditambahkan 5 $\mathrm{mL}$ aseton. Setelah itu, larutan diencerkan dengan menambahkan aqua DM hingga tanda batas kemudian diukur absorbansinya pada rentang panjang gelombang 400-600 nm menggunakan spektrofotometer UV-Vis. dan digunakan larutan blanko sebagai pembanding.

\section{Pembuatan Kurva Kalibrasi}

Kurva kalibrasi dibuat dari pengukuran absorbansi campuran larutan yang terbuat dari 0,2 $\mathrm{mL}$ larutan $\mathrm{Fe}^{2+} 50 \mathrm{ppm}, 1,5 \mathrm{~mL}$ larutan 1,10fenantrolin $1000 \mathrm{ppm}$, dan $1 \mathrm{~mL}$ larutan buffer asetat $\mathrm{pH} 4,5$ yang dimasukkan ke dalam labu ukur $10 \mathrm{~mL}$. Campuran larutan didiamkan selama \pm 60 menit, lalu ditambahkan $5 \mathrm{~mL}$ aseton. Setelah itu, larutan diencerkan dengan menambahkan aqua DM hingga tanda batas, kemudian diukur absorbansinya pada panjang gelombang maksimum yang telah ditentukan sebelumnya. Larutan blanko digunakan sebagai pembanding. Prosedur tersebut diulangi dengan menggunakan jumlah volume larutan $\mathrm{Fe}^{2+}$ 0,$4 ; 0,6 ; 0,8$ dan $1 \mathrm{~mL}$

\subsection{Standarisasi Larutan Ce $\mathrm{C}^{4+} 150 \mathrm{ppm}$}

Larutan $\mathrm{Ce}^{4+} 150 \mathrm{ppm}$ yang telah dibuat, distandarisasi dengan larutan $\mathrm{Fe}^{2+} 50$ ppm $5 \mathrm{~mL}$ dan digunakan 1 tetes feroin sebagai indikator. Prosedur diulang sebanyak tiga kali dan digunakan larutan blanko (campuran aqua DM $5 \mathrm{~mL}$ dengan 1 tetes indikator feroin) sebagai pembanding

\subsection{Pengukuran Kadar Besi dengan Titrasi \\ Serimetri dan Spektrofotometer UV-Vis}

Pengukuran kadar besi dilakukan dengan dua cara yaitu titrasi serimetri dengan menggunakan $\mathrm{Ce}^{4+} 150 \mathrm{ppm}$ yang telah distandarisasi sebagai titran dan menggunakan instrumen spektrofotometri $\mathrm{UV}-\mathrm{Vis}$.

Larutan $\mathrm{Fe}^{2+} 50$ ppm diambil sebanyak $3 \mathrm{~mL}$ dan dimasukan ke dalam labu ukur $50 \mathrm{~mL}$, ditambahkan 7,5 mL larutan 1,10-fenantrolin 1000 ppm, kemudian tepatkan $\mathrm{pH}$ larutan menjadi 4,5 dengan ditambahkan $5 \mathrm{~mL}$ larutan buffer asetat $\mathrm{pH}$ 4,5. Campuran larutan didiamkan selama \pm 60 menit, lalu ditambahkan $25 \mathrm{~mL}$ aseton dan diencerkan dengan menambah aqua DM hingga tanda batas.

Larutan yang telah jadi dibagi menjadi dua bagian. Larutan bagian pertama diukur absorbansinya pada panjang gelombang maksimum yang telah ditentukan sebelumnya dan digunakan larutan blanko sebagai pembanding. Titrasi bagian yang lain dengan menggunakan $\mathrm{Ce}^{4+} 150 \mathrm{ppm}$ dan dicatat volume titran yang diperlukan sampai titik akhir titrasi tercapai. Bandingkan kadar besi yang terukur dari kedua metode tersebut. Prosedur tersebut diulangi dengan menggunakan jumlah volume larutan $\mathrm{Fe}^{2+} 1,5 \mathrm{~mL}$, dan diulang sebanyak tiga kali. 


\section{Hasil dan Diskusi}

\subsection{Penentuan Panjang Gelombang Maksimum dan Pembuatan Kurva Kalibrasi}

Senyawa $\mathrm{Fe}(\mathrm{II})$-fenantrolin membentuk kompleks dengan ligan 1,10-fenantrolin, berikut reaksinya:

$$
\mathrm{Fe}^{2+}+3 \text { Phen } \longrightarrow\left[\mathrm{Fe}(\mathrm{II})(\text { phen })_{3}\right]^{2+}
$$

Panjang gelombang maksimum dapat diketahui dari absorbansi tertinggi hasil pengukuran menggunakan instrumen spektrofotometer UV-Vis. Rentang panjang gelombang yang digunakan adalah $400-600 \mathrm{~nm}$ dengan interval $1 \mathrm{~nm}$ karena senyawa kompleks Fe(II)-fenantrolin memiliki warna jingga kemerahan dengan warna dasar merah dimana warna merah merupakan warna komplementer sehingga warna yang terserap pada spektrofotometer UV-Vis adalah hijau-biru yang memiliki panjang gelombang sekitar 500-520 nm dan penggunaan intreval $1 \mathrm{~nm}$ dimaksudkan agar penguran panjang gelombang lebih akurat. Berdasarkan Gambar 1, absorbansi tertinggi terletak panjang gelombang 510 nm yaitu sebesar 0,564 .

Kurva kalibrasi dibuat dari pengukuran absorbansi larutan standar Fe(II)-fenantrolin dengan konsentrasi yaitu $0-5 \mathrm{ppm}$. Nilai absorbansi hasil pengukuran dibuat menjadi kurva kalibrasi seperti yang terlihat pada Gambar 2 dimana sumbu $x$ adalah konsentrasi dan sumbu y adalah absorbansi. Kurva tersebut memiliki nilai regresi $\mathrm{R}^{2}=0,9997$ dan persamaan linier $\mathrm{y}=0,2067 \mathrm{x}+0,0030$. Persmaan linier tersebut digunakan dalam perhitungan penentuan kadar besi pada sampel $\mathrm{Fe}(\mathrm{II})$ fenantrollin yang telah dibuat.

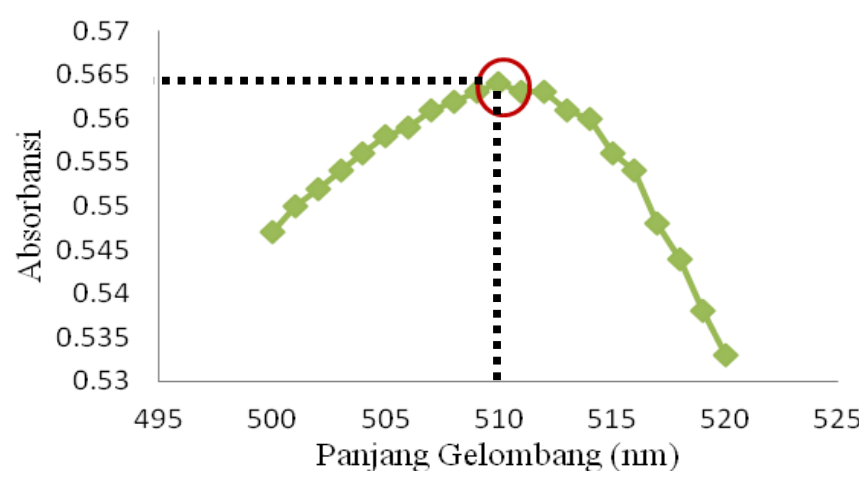

Gambar.1. Panjang gelombang maksimum kompleks Fe(II)-fenantrolin

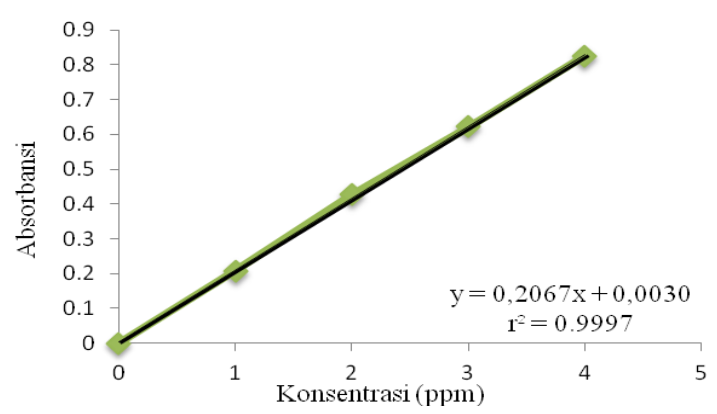

Gambar. 2. Kurva kalibrasi larutan standar besi(II)fenantrolin.

\subsection{Standarisasi Larutan $\mathrm{Ce}^{4+} 150 \mathrm{ppm}$}

Larutan $\mathrm{Ce}^{4+} 150$ ppm dibuat dengan melarutkan 0,0404 gram $\mathrm{Ce}\left(\mathrm{SO}_{4}\right)_{2} .4 \mathrm{H}_{2} \mathrm{O}$ dengan aqua DM dalam labu ukur $100 \mathrm{~mL}$. Pada proses pembuatan larutan, ditambahkan $15 \mathrm{~mL} \mathrm{H}_{2} \mathrm{SO}_{4} 5 \mathrm{M}$. Penambahan asam kuat tersebut dilakukan agar $\mathrm{Ce}\left(\mathrm{SO}_{4}\right)_{2} \cdot 4 \mathrm{H}_{2} \mathrm{O}$ terlarut sempurna serta sebagai pembuat suasana asam sehingga pada saat titrasi tidak terjadi hidrolisis dari garam serium (IV) sulfat menjadi $\mathrm{Ce}(\mathrm{OH})_{4}$ yang mengendapan, dimana nantinya akan mengganggu dalam penetapan $\operatorname{kadar}^{[7]}$.

Larutan $\mathrm{Ce}^{4+}$ yang telah dibuat perlu distandarisasi karena di dalam larutan terdapat kemungkinan adanya ion lain yang dapat membentuk kompleks stabil dengan $\mathrm{Ce}^{4+}$, misalnya $\mathrm{CeX}_{6}^{2-}$ yang menyebabkan potensial oksidasi menurun. Larutan $\mathrm{Ce}^{4+} 150 \mathrm{ppm}$ distandarisasi dengan larutan $\mathrm{Fe}^{2+} 50$ ppm dengan bantuan indikator feroin. Indikator ini berfungsi untuk memperjelas perubahan warna yang terjadi pada titik akhir titrasi ${ }^{[7]}$.

Standarisasi larutan $\mathrm{Ce}^{4+} 150 \mathrm{ppm}(0,001 \mathrm{M})$ dengan $5 \mathrm{~mL}$ larutan $\mathrm{Fe}^{2+} 50$ ppm $(0,000895 \mathrm{M})$ dilakukan sebanyak tiga kali (untuk menambah ketepatan hasil) dengan penambahan 1 tetes indikator feroin. Pada proses standarisasi ini, digunakan juga larutan blanko yang berfungsi sebagai faktor pengoreksi ${ }^{[2]}$.

Proses standarisasi dihentikan ketika titik akhir titrasi tercapai. Tercapainya titik akhir titrasi ditandai dengan perubahan warna dari merah menjadi biru pucat. Timbulnya warna biru pucat ini akibat terjadinya perpindahan elektron pada orbital $\mathrm{d}$, yaitu dari orbital yang tingkat energinya lebih rendah ke orbital yang tingkat energinya lebih tinggi dan kembali lagi ke tingkat energi rendah dengan memancarkan energi. Warna yang muncul sebagai warna senyawa kompleks tersebut adalah warna komplemen dari warna yang diserap dalam proses 
eksitasi $^{[1]}$. Selain itu, warna biru pucat ini adalah tanda terbentuknya kompleks Fe(III)-fenantrolin. Hal tersebut sesuai dengan reaksi reduksi-oksidasi berikut ini ${ }^{[7]}$.

\begin{tabular}{llll} 
Oksidasi $\quad: \mathrm{Fe}^{2+}$ & $\rightarrow \mathrm{Fe}^{3+}+\mathrm{e}^{-}$ \\
Reduksi $\quad: \mathrm{Ce}^{4+}+\mathrm{e}^{-} \rightarrow$ & $\mathrm{Ce}^{3+}$ \\
\hline Redoks $: \mathrm{Fe}^{2+}+\mathrm{Ce}^{4+} \rightarrow$ & $\mathrm{Ce}^{3+}+\mathrm{Fe}^{3+}$
\end{tabular}

Berdasarkan reaksi reduksi oksidasi diatas, terlihat bahwa berat ekivalen (BE) dari $\mathrm{Fe}^{2+}$ adalah sama dengan berat molekulnya karena hanya dibutuhkan 1 mol Fe${ }^{2+}$ untuk membentuk $1 \mathrm{~mol} \mathrm{Fe}^{3+}$ dengan melepas 1 elektron (reaksi oksidasi/ reduktor). Begitu pula dengan $\mathrm{Ce}^{4+}$, dimana hanya dibutuhkan 1 mol $\mathrm{Ce}^{4+}$ untuk membentuk $1 \mathrm{~mol}$ $\mathrm{Ce}^{3+}$ dengan menyerap 1 elektron (reaksi reduksi/ oksidator). Sehingga valensinya dari $\mathrm{Fe}^{2+}$ dan $\mathrm{Ce}^{3+}$ adalah $1^{[7]}$. Standarisasi yang telah dilakukan menghasilkan data sebagai berikut ini :

Tabel 1 Hasil Standarisasi Larutan $\mathrm{Ce}^{4+}$

\begin{tabular}{|l|c|}
\hline \multicolumn{1}{|c|}{ Keterangan } & $\begin{array}{c}\text { Volume Larutan } \mathbf{C e}^{\mathbf{4 +}} \\
(\mathbf{m L})\end{array}$ \\
\hline Volume percobaan 1 & 7,0 \\
Volume percobaan 2 & 6,8 \\
Volume percobaan 3 & 6,9 \\
Volume rata-rata & 6,9 \\
Volume blanko & 0,9 \\
\hline
\end{tabular}

Berdasarkan Tabel 1, volume larutan $\mathrm{Ce}^{4+}$ yang digunakan dalam penentuan konsentrasi larutan $\mathrm{Ce}^{4+}$ yang sebenarnya adalah $6 \mathrm{~mL}$ (sudah dikurangi volume larutan blanko). Sehingga didapatkan konsentrasi larutan $\mathrm{Ce}^{4+}$ sebesar 0,00075 N. Karena valensi dari $\mathrm{Fe}^{2+}$ dan $\mathrm{Ce}^{3+}$ adalah 1, maka konsentrasi larutan $\mathrm{Ce}^{4+}$ dalam molar juga sama dengan normalnya, yaitu $0,00075 \mathrm{M}$. Konsentrasi yang didapat, digunakan sebagai konsentrasi larutan $\mathrm{Ce}^{4+}$ untuk pengukuran kadar besi dalam sampel.

\subsection{Kadar Besi pada Fe(II)-Fenantrolin 1,5 ppm dan 3 ppm}

Pada pengukuran kadar besi, dibuat sampel yang berasal dari campuran $\mathrm{Fe}^{2+} 50$ ppm dan 1,10fenantrolin dengan konsentrasi 1,5 dan $3 \mathrm{ppm}$. Campuran tersebut membentuk kompleks $\mathrm{Fe}$ (II)- fenantrolin yang berwarna merah jingga. kompleks yang telah dibuat kemudian dibagi menjadi dua bagian (A dan B), dimana sampel A diuji kadar besi yang terkandung menggunakan metode spektrofotometer UV-Vis dan sampel B diuji kadar besi yang terkandung menggunakan metode serimetri.

Pada sampel A, kompleks Fe(II)-fenantrolin 1,5 ppm dan 3 ppm masing-masing diukur absorbansinya dengan spektrofotometri UV-Vis pada panjang gelombang maksimum $510 \mathrm{~nm}$. Sedangkan pada sampel B, kompleks $\mathrm{Fe}$ (II)fenantrolin 1,5 ppm dan 3 ppm masing-masing diukur konsentrasinya dengan metode titrasi menggunakan larutan $\mathrm{Ce}^{4+} 0,00075 \mathrm{M}$. Pengukuran tersebut diulang sebanyak lima kali kali untuk menambah ketepatan hasil dan mengurangi kesalahan dalam penelitian serta digunakan blanko sebagai pembanding ${ }^{[2]}$.

Hasil pengukuran absorbansi (sampel A) dan konsentrasi (sampel B) yang didapat dirata-rata dan dihitung persen perolehan kembali (persen recovery), Relative Standard Deviation (RSD) dan Coefficient of Variation (CV) untuk mengetahui validitas suatu prosedur analisa dan untuk mengetahui derajat kedekatan hasil analis dengan kadar analit yang sebenarnya (akurasi) ${ }^{[4]}$. Sehingga dapat ditentukan metode mana yang lebih baik untuk pengukuran kadar besi.

Pada pengukuran absorbansi sampel A, nilai absorbansi yang didapat diolah melalui persamaan linier yang berasal dari kurva kalibrasi yang telah dibuat sebelumnya untuk mendapatkan kadar besi dalam sampel. Pada sampel dengan konsentrasi awal 1,5 ppm didapatkan rata-rata nilai absorbansi $0,330(105,596 \%)$ dan pada konsentrasi awal 3 ppm didapatkan rata-rata nilai absorbansi 0,635 $(101,91 \%)$. Hasil pengukuran absorbansi dan hasil perhitungan persen recovery ditunjukkan pada Tabel 2.

Pada sampel B, pengukuran konsentrasi besi yang didapat diolah melalui rumus titrasi dengan $\mathrm{N}_{1}$ adalah normalitas larutan $\mathrm{Ce}^{4+} 0,00075 \mathrm{M}$ (titran). Dari perhitungan tersebut didapatkan konsentrasi besi dengan satuan normal $(\mathrm{N})$, yang kemudian dikonversikan menjadi satuan molar (M). Berdasarkan Tabel 2 diatas, terlihat bahwa pada sampel dengan konsentrasi awal 1,5 ppm $(0,000027$ M) didapatkan konsentrasi akhir $0,00003 \mathrm{M}$ $(111,111 \%)$ dan pada konsentrasi awal 3 ppm $(0,0000537$ M) didapatkan konsentrasi akhir 0,00006 M (111,731\%). 
Tabel 2 Hasil Pengukuran Absorbansi dan Hasil Perhitungan Persen Recovery Sampel A

\begin{tabular}{|c|c|c|c|c|c|c|c|c|}
\hline \multirow{2}{*}{$\begin{array}{c}\text { Kons. } \\
\begin{array}{c}\text { Awal } \\
\text { Sampel } \\
(\mathbf{p p m})\end{array}\end{array}$} & \multicolumn{4}{|c|}{ Absorbansi (Abs.) } & \multirow{2}{*}{$\begin{array}{c}\text { Abs. } \\
\text { Rata- } \\
\text { rata }\end{array}$} & $\begin{array}{c}\text { Kons. Akhir } \\
\text { Sampel } \\
\text { (ppm) }\end{array}$ & \% Rec (\%) \\
\hline 1,5 & 0,330 & 0,329 & 0,329 & 0,330 & 0,334 & 0,330 & 1,584 & 105,596 \\
\hline 3 & 0,636 & 0,640 & 0,641 & 0,630 & 0,628 & 0,635 & 3,058 & 101,919 \\
\hline
\end{tabular}

Tabel 3 Hasil Titrasi dan Hasil Perhitungan Persen Recovery Sampel B

Tabel 3 Hasil Titrasi dan Hasil Perhitungan Persen Recovery Sampel B

\begin{tabular}{|c|c|c|c|c|c|c|c|c|}
\hline $\begin{array}{c}\text { Kons. } \\
\text { Awal } \\
\text { Sampel } \\
(\mathbf{M})\end{array}$ & $\mathbf{B}_{\mathbf{1}}$ & $\mathbf{B}_{\mathbf{2}}$ & $\mathbf{B}_{\mathbf{3}}$ & $\mathbf{B}_{\mathbf{4}}$ & $\mathbf{B}_{\mathbf{5}}$ & \begin{tabular}{c} 
Vol. Titran \\
\cline { 2 - 8 } \\
rata- \\
rata \\
$(\mathbf{m L})$
\end{tabular} & $\begin{array}{c}\text { Kons. Akhir } \\
\text { Sampel } \\
(\mathbf{M})\end{array}$ & \% Rec (\%). \\
\hline 0,0000270 & 1,5 & 1,3 & 1,5 & 1.5 & 1.4 & 1,4 & 0,00003 & 111,111 \\
\hline 0,0000537 & 1,5 & 1,6 & 1,5 & 1.7 & 1.7 & 1,6 & 0,00006 & 111,731 \\
\hline
\end{tabular}

Volume yang diperlukan untuk titrasi sampel B dan hasil perhitungan persen recovery ditunjukkan pada Tabel 3.

Berdasarkan persen recovery yang didapat, pada sampel A $(105,596 \%$ dan 101,919\%) telah sesuai dengan batas persen recovery yang dapat diterima, yaitu pada rentang $8-110 \%$. Namun, persen recovery yang didapat pada sampel B $(111,111 \%$ dan $111,731 \%)$ sedikit keluar dari batas persen recovery yang dapat diterima ${ }^{[9]}$. Sehingga berdasarkan perhitungan persen recovery, terlihat bahwa metode yang paling baik digunakan untuk mengukur kadar besi dalam sampel adalah dengan menggunakan spektrofotometer UV-Vis.

Hasil pengukuran absorbansi (Tabel 2) dan hasil titrasi (Tabel 3) selanjutnya dihitung RSD dan $\mathrm{CV}$ untuk mengetahui derajat kesamaan (presisi) antar hasil yang terukur, dimana nilai CV yang memenuhi syarat, menandakan bahwa instrumen mampu memberikan keterulangan deteksi analat yang baik ${ }^{[4]}$. Pada penelitian kali ini, syarat nilai CV yang diterima adalah kurang dari $16 \%$, karena konsentrasi sampel yang digunakan adalah $\mathrm{ppm}^{[3]}$. Berikut hasil perhitungan RSD dan CV pada sampel A dan B :

Berdasarkan nilai $\mathrm{CV}$ yang didapat, pada sampel A $(0,64 \%$ dan $0,91 \%)$ dan pada sampel B $(6,18 \%$ dan $6,25 \%)$ telah sesuai dengan batas nilai RSD yang dapat diterima, yaitu kurang dari $16 \%$.
Berdasarkan hasil tersebut, nilai CV pada sampel A lebih kecil daripada nilai $\mathrm{CV}$ pada sampel $\mathrm{B}$. Sehingga terlihat bahwa metode yang paling baik digunakan untuk mengukur kadar besi dalam sampel adalah dengan menggunakan spektrofotometer UVVis.

\section{Tabel 4 Hasil Perhitungan RSD dan CV pada} Sampel

\begin{tabular}{|c|c|c|c|c|}
\hline \multirow{2}{*}{ Sampel } & $\begin{array}{c}\text { Konsentrasi } \\
\text { Sampel } \\
(\mathbf{p p m})\end{array}$ & $\begin{array}{c}\text { Standar } \\
\text { Deviasi }\end{array}$ & RSD & $\begin{array}{c}\text { CV } \\
(\%)\end{array}$ \\
\hline \multirow{2}{*}{$\mathrm{A}$} & 1,5 & 0,0019 & 0,0058 & 0,64 \\
\cline { 2 - 5 } & 3 & 0,0052 & 0,0082 & 0,91 \\
\hline \multirow{2}{*}{$\mathrm{B}$} & 1,5 & 0,0866 & 0,0618 & 6,18 \\
\cline { 2 - 5 } & 3 & 0,1000 & 0,0625 & 6,25 \\
\hline
\end{tabular}

\section{KESIMPULAN}

Berdasarkan penelitian yang telah dilakukan, diperoleh bahwa hasil analisa kadar besi menggunakan spektrofotometer UV-Vis mempunyai nilai CV yang lebih kecil, yaitu $0,64 \%$ (1,5 ppm) dan $0,91 \%$ (3 ppm) dibandingkan dengan metode serimetri, yaitu 6,18\% (1,5 ppm) dan 6,25\% (3 ppm). Hasil perhitungan persen recovery kadar besi yang diukur menggunakan spektrofotometer UV-Vis sebesar 105,596\% (1,5 ppm) dan 101,919\% (3 ppm), 
sedangkan pada metode serimetri sebesar $111,111 \%$ (1,5 ppm) dan $111,731 \%$ (3 ppm). Hasil persen recovery yang didapat pada metode serimetri melebihi batas persen recovery yang diterima, yaitu pada rentang 80-110\%. Berdasarkan nilai CV dan persen recovery tersebut, maka dapat disimpulkan bahwa metode yang paling baik digunakan untuk mengukur kadar besi adalah menggunakan spektrofotometer UV-Vis.

\section{UCAPAN TERIMA KASIH}

Penulis mengucapkan terima kasih pada Bapak Djarot Sugiarso K.S. atas bimbingannya selama penelitian hingga skripsi selesai. Bapak dan Ibu dosen Kimia ITS atas semua ilmu dan saran yang telah diberikan. Orang tua, keluarga dan oranng terkasih serta teman - teman yang selalu memberikan dukungan dan doa.

\section{DAFTAR PUSTAKA}

[1] Atkins, P.W. (1990). Physical Chemistry. Oxford: Oxford University Press.
[2] Cochran, W. G (1991). Teknik Penarikan Sampel (Terjemahan) Jilid III. Jakarta: UI-Press.

[3] Demaeyer, E. M. (1993). Pencegahan dan Pengawasan Anemia Defisiensi Besi. Jakarta: Widya Medika.

[4] Harmita. (2004). Petunjuk Pelaksanaan Validasi Metode Dan Cara Perhitungannya. Majalah Ilmu Kefarmasian. 1(3). 117 - 135.

[5] Joyce, L. K dan Evelyn, R. H. (1996). Farmakologi. Pendekatan Proses Keperawatan. Jakarta: EGC.

[6] Kim, E. C and Nikolaev, V. I. (1995). Methods For Determining The Iron In Medicines. Journal of the Korean Physical Society. 28 (2), pp. 188-192

[7] Mursyidi, A dan Rohman, A. (2006). Pengantar Kimia Farmasi Analisis Volumetri dan Gravimetri. Yogyakarta: Pustaka Pelajar.

[8] Setyowati. (2009). Validasi dan Pengembangan Penetapan Kadar Tablet Besi (II) Sulfat dengan Spektrofotometri Visibel dan Serimetri sebagai Pembanding. Surakarta: UMMU.

[9] Wood, R. A.N., \& Wallin, H. (1998). Quality in the Food Analysi. Laboratory the Royal Society of Chemistry. Cambridge 
